\title{
Teoretyczne badania konfrontatywne
}

\section{Wstęp}

Teoretyczne badania konfrontatywne są domeną Zespołu Semantyki (zespol.semantyki@ispan.waw.pl) Instytutu Slawistyki Polskiej Akademii Nauk (http://www.ispan.waw.pl/). Formalnie Zespół Semantyki powstał w 1997 roku wraz $\mathrm{z}$ reorganizacją struktury Instytutu. Tej daty nie można jednak utożsamiać z początkiem badań semantycznych w IS PAN, albowiem Zespół Semantyki kontynuuje zadania naukowe dawnej Pracowni Języków Południowosłowiańskich rozpoczęte $\mathrm{z}$ końcem lat 70. minionego wieku. Zmiana nazwy zespołu była konieczna, ponieważ w pełni nie odzwierciedlała zarówno zakresu, jak i kierunku tam prowadzonych badań. Zespół współtworzyła i przez wiele lat kierowała nim Violetta Koseska-Toszewa. Na początku XXI wieku wraz z rozszerzeniem zakresu badań na kolejne języki naturalne formuła Zespołu Semantyki uległa zmianie. Zespół nadal prowadzi badania z zakresu najnowszych dziedzin językoznawstwa współczesnego: semantyki, również w ujęciu kognitywnym, teoretycznych badań konfrontatywnych oraz językoznawstwa korpusowego czy elektronicznych słowników sieciowych. Jednak (od 2010 roku) w ramach Zespołu Semantyki wyróżnia się dwa współpracujące ze sobą podzespoły. Jednym z nich kieruje Violetta Koseska-Toszewa (zakres badań: semantyka, konfrontacja językowa, lingwistyka korpusowa i badania kognitywne ograniczone do języków słowiańskich), drugim zaś Roman Roszko (zakres badań: semantyka i konfrontacja bałtosłowiańska oraz 
lingwistyka komputerowa). Oba podzespoły ściśle współpracują w następujących tematach: a) słownik terminologiczny (opracowywany dla języków słowiańskich, bałtyckich i innych), b) Cognitive Studies/Études Cognitives (badania kognitywne języków naturalnych).

\section{O teoretycznych badaniach konfrontatywnych}

Teoretyczne badania konfrontatywne Zespołu Semantyki są utrzymane w nurcie synchronicznych badań teoretycznych, których podstawą jest język-pośrednik. Termin "język-pośrednik” został wprowadzony do literatury przedmiotu na etapie dyskusji nad projektem polsko-bułgarskiej i serbsko-chorwacko-polskiej gramatyki konfrontatywnej na przełomie lat 70. i 80. minionego wieku (por. Projekt 1984). Wykorzystany na potrzeby teoretycznych badań konfrontatywnych termin ten nawiązywał do przemyśleń Selinkera zawartych w pracy z początku lat 70. XX wieku (Selinker 1972). Język-pośrednik, pełniący w teoretycznych badaniach konfrontatywnych rolę semantycznego tertium comparationis, wraz $\mathrm{z}$ postępującymi badaniami podlega rozwojowi. Jego zastosowanie w konfrontacji językowej pozwala wyeliminować charakterystyczne dla wcześniejszych badań konfrontatywnych błędne podejście ukierunkowane od formy do treści lub inaczej ujmując - podejście wychodzące od analizy form języka wyjściowego/rodzimego i zmierzające do ukazania znaczeniowych odpowiedników tychże form w języku docelowym/ obcym. Teoretyczne badania konfrontatywne dążą do opisu uniwersaliów językowych. W odróżnieniu od badań konfrontatywnych o zastosowaniu praktycznym teoretyczne badania konfrontatywne nie są ukierunkowane na wyodrębnienie z języków cech wspólnych i różnicujących, choć również w nich takie wnioski są możliwe. Teoretyczne badania konfrontatywne są badaniami wybitnie synchronicznymi. W pewnym sensie nawiązują również do badań typologicznych, jednak celem teoretycznych badań konfrontatywnych nie jest klasyfikacja języków, jak to ma miejsce w wypadku badań typologicznych, lecz analiza systemowa zestawianych języków. Stosowane w teoretycznych badaniach konfrontatywnych podejście semantyczne pozwala wykryć i opisać sposoby wyrażania informacji nieskategoryzowanych oraz uniwersaliów empirycznych, co przy zestawianiu samych form nie jest możliwe. Zatem charakterystyczna dla teoretycznych badań konfrontatywnych procedura analizy ukierunkowana od planu znaczeniowego do płaszczyzny formalnej daje pełniejszy obraz poszczególnych kategorii semantycznych wspólnych zestawianym językom, w przeciwieństwie do metody opartej na interpretacji znaczeń form języka wyjściowego za pomocą form języka docelowego. W wypadku 
opisu kategorii semantycznych nie zachodzi konieczność, by wiązane z nimi kategorie morfologiczne funkcjonowały w obu zestawianych językach. Ponadto, teoretyczne badania konfrontatywne nie wykluczają opisu takich kategorii semantycznych, które w żadnym zestawianym języku nie posiadają regularnych wykładników morfologicznych (tj. kategorii morfologicznych). Na ten temat por. (Koseska, Korytkowska, Roszko 2007).

Pionierskim opracowaniem Zespołu Semantyki (powstałym we współpracy z Bułgarską Akademią Nauk) była Gramatyka konfrontatywna butgarsko-polska (Koseska, Penčev 1988-2009). Wraz z opracowywaniem kolejnych tomów Gramatyki język-pośrednik ewoluował. Do już zdefiniowanych w języku-pośredniku znaczeń dochodziły nowe treści związane z kolejnymi opisywanymi kategoriami semantycznymi. W procesie tworzenia języka-pośrednika obowiązuje zasada wewnętrznej zgodności, niesprzeczności. Ponadto językowi-pośrednikowi stawia się wymóg jasności i przejrzystości struktur. Nadmierna komplikacja treści nie jest wskazana. Oczekuje się też, że wykorzystane w kształtowaniu języka-pośrednika teorie pozwolą na tzw. informatyzację zapisów. Oznacza to, że definiowane znaczenia w sposób jednoznaczny i ścisły mogą zostać oddane za pomocą sformalizowanych zapisów, które z kolei mogą zostać wykorzystane w komputerowym przetwarzaniu języka (np. w lingwistyce korpusowej, na potrzeby elektronicznych słowników sieciowych itd.). Ukształtowany przez autorów Gramatyki język-pośrednik nie jest jedyną słuszną propozycją tertium comparationis opracowaną na cele konfrontacji językowej. Nie chodzi tu tylko o wykorzystanie w tworzeniu języka-pośrednika tych czy innych teorii, lecz również o sam aspekt złożoności samej struktury. W założeniach teoretycznych badań konfrontatywnych stwierdza się bowiem, że stopień złożoności języka-pośrednika musi jak najbardziej odpowiadać strukturom zestawianych języków. Dlatego język-pośrednik w sytuacjach tego wymagających może zostać rozbudowany o nowe zjawiska, które w konfrontacji nowych języków odpowiednio uszczegółowią definiowane znaczenia. Natomiast na potrzeby konfrontacji innych języków może zajść konieczność jego uproszczenia. Uszczegółowienie czy uproszczenie struktury języka-pośrednika nie powinno naruszać zasady zgodności wstecz. Dlatego modyfikacja języka-pośrednika nie może wyznaczać nowych podziałów, które nie byłyby a) wewnętrznym uszczegółowieniem już istniejącego znaczenia lub b) scaleniem już wyróżnionych podznaczeń. W ten sposób zachowana zgodność strukturalna $\mathrm{z}$ wcześniejszą wersją języka-pośrednika powoduje, że zestawienie wyników oddzielnie prowadzonych badań, nawet przez różne zespoły badawcze, staje się proste i pozbawione błędów terminologicznych 
czy metodologicznych. Ponadto możliwa jest dowolna konfiguracja aktualnie zestawianych języków. Na przykład w oparciu o istniejące już badania polsko-litewskie i bułgarsko-polskie możliwe są poniższe konfiguracje: bułgarsko-litewska oraz bułgarsko-polsko-litewska. Należy nadmienić, że kolejność języków wyróżnianych konfiguracji może mieć jedynie wartość umowną (stylistyczną), albowiem punktem wyjścia i nieustającego odniesienia $\mathrm{w}$ teoretycznych badaniach konfrontatywnych jest zawsze język-pośrednik. We wcześniejszych (ostro krytykowanych w latach 60.-70. $\mathrm{XX}$ w.) badaniach konfrontatywnych kolejność wymieniania języków odzwierciedlała kierunek przeprowadzonych badań. Pierwszy z wymienianych języków był językiem wyjściowym, drugi z nich - językiem docelowym.

\subsection{Kategoria morfologiczna a kategoria semantyczna}

W gramatykach szkolnych i akademickich opisywane są kategorie morfologiczne, czyli takie klasy form gramatycznych, które zostają wyróżnione w oparciu o regularny element formalny, morfologiczny (np. sufiks), i które charakteryzują się tym, że spełniają pewną funkcję językową. Natomiast u podstaw wyróżnienia kategorii semantycznych nie leży żaden element formalny języka. Kategorie semantyczne nie są więc właściwe formalnej płaszczyźnie języka. Są przynależne do wyższego poziomu - do semantycznej/ znaczeniowej płaszczyzny języka. Kategorie semantyczne są elementem uniwersalnym dla wszystkich języków. To one łączą wszystkie języki naturalne. Kategorie morfologiczne są tylko przybliżonym, częściowym odzwierciedleniem kategorii semantycznych. Inaczej mówiąc, kategorie morfologiczne różnią języki, zaś kategorie semantyczne - jako uniwersalia - łączą.

W tradycyjnych opracowaniach dla każdej kategorii morfologicznej wyróżnia się podstawową opozycję członu nacechowanego do członu nienacechowanego. W wypadku morfologicznej kategorii określoności/ nieokreśloności człon nacechowany, kojarzony najczęściej (przynajmniej w badaniach nad językami germańskimi i romańskimi) z użyciem tzw. rodzajnika określonego we frazie imiennej, jest wyznacznikiem określoności. Człon nienacechowany tej opozycji, łączony z użyciem tzw. rodzajnika nieokreślonego we frazie imiennej, jest zaś wyznacznikiem nieokreśloności. Poniżej zostają przedstawione przykłady podstawowej opozycji morfologicznych kategorii określoności/nieokreśloności dla kilku języków naturalnych.

2.1.1. Morfologiczna kategoria określoności/nieokreśloności w języku angielskim bazuje na opozycji użycia rodzajników: określonego the (stoso- 
wanego dla obu liczb - pojedynczej i mnogiej) do nieokreślonego a/an (stosowanego jednak już tylko dla liczby pojedynczej). Ilustracją powyższego może być poniższa opozycja fraz nominalnych:

the boy 'ten chłopiec' : a boy 'jakiś chłopiec'.

Bardzo zbliżoną postać morfologicznej kategorii określoności/nieokreśloności do przedstawionej obserwujemy chociażby w języku niemieckim.

2.1.2. W języku bułgarskim morfologiczna kategoria określoności/nieokreśloności opiera się na opozycji postpozycyjnego rodzajnika $-\preccurlyeq m /-a$ do tzw. zera morfologicznego $ø$, czyli braku materialnie wyróżnionego rodzajnika. W pewnym stopniu ta cecha zbliża język bułgarski z językami niemieckim czy angielskim, w których dla form pluralnych obserwujemy identyczne zjawisko, por.:

bułg. човекъm/човека 'ten człowiek' : човек (= човек-ø) 'jakiś człowiek' ang. the books 'te książki' : books (=ø books) 'jakieś książki', niem. die Bücher 'te książki' : Bücher (=ø Bücher) 'jakieś książki'.

2.1.3. W językach bałtyckich (litewski i łotewski) morfologiczną kategorię określoności/nieokreśloności wyznacza opozycja form o odmianie złożonej (zaimkowej) do form o odmianie prostej. Poniżej ilustracja $\mathrm{z}$ języka litewskiego:

gerasis 'ten dobry' : geras 'jakiś dobry', gdzie gerasis (odmiana złożona, człon nacechowany), geras (odmiana prosta, człon nienacechowany). W wypadku języka litewskiego można zaobserwować pewne podobieństwo do języka bułgarskiego. Otóż w obu językach człony nacechowane zawsze posiadają element dodany, por. bułg. човекъm i litew. gerasis. O ile dla języka bułgarskiego element dodany jest tzw. rodzajnikiem określonym, o tyle w litewskiej terminologii element dodany jest wyróżnikiem deklinacji złożonej zaimkowej ${ }^{1}$. Natomiast człony nienacechowane nie posiadają żadnego formalnego wyróżnika, por. bułg. човек 'jakiś człowiek' i litew. geras 'jakiś dobry'.

Przedstawione wyżej bułgarsko-litewskie odpowiedniości mogłyby świadczyć o dużych analogiach między morfologicznymi kategoriami określoności/nieokreśloności w obu tych językach. Jednak należy zauważyć, że stosowanie litewskich form o odmianie złożonej jest ograniczone tylko do form przymiotników jakościowych i imiesłowów. Dlatego przedstawionej wyżej (2.1.2.) bułgarskiej parze opozyсуjnej човекъm/човека 'ten człowiek' : човек (= човек- $\varnothing)$ 'jakiś człowiek' nie może odpowiadać litewska * žmogusis : žmogus, bo žmogus 'człowiek' jest rzeczownikiem. Natomiast

\footnotetext{
${ }^{1} \mathrm{Z}$ diachronicznego punktu widzenia w obu językach stwierdza się identyczny proces.
} 
możliwa jest litewska para opozycyjna gerasis žmogus 'ten dobry człowiek' : geras žmogus 'jakiś dobry człowiek’, bo w wyrażeniu złożonym występuje przymiotnik jakościowy. W tym ostatnim wypadku litewskiej opozycji dokładnie odpowiada bułgarska para: добрият човек 'ten dobry człowiek' : : добър човек 'jakiś dobry człowiek'.

Przeprowadzona w (Roszko 2004) analiza języka litewskiego ujawnia nieopisywany w literaturze analogiczny do języków angielskiego czy niemieckiego sposób wyróżnienia członu nacechowanego za pomocą zaimka tas 'ten,', por. tas žmogus 'ten człowiek' : žmogus 'jakiś człowiek' i ang. the man : a man/ niem. der Mensch : ein Mensch. W litewskiej literaturze przedmiotu forma tas 'ten,' nie zostaje jednak ujęta jako element morfologicznej kategorii określoności/nieokreśloności (jako rodzajnik), ponieważ wymogi formalne stawiane kategoriom morfologicznym nie zezwalają na łączenie $\mathrm{w}$ jedną kategorię różnych z formalnego punktu widzenia wykładników (tu tzw. rodzajników). Dlatego w litewskiej literaturze przedmiotu o morfologicznej kategorii określoności/nieokreśloności mówi się w kontekście form o odmianie zaimkowej (element nacechowany znajduje się $\mathrm{w}$ postpozycji, stosowana jest pisownia łączna), nigdy zaś w kontekście formy tas 'ten,' W zasadzie - pozostając w zgodzie z regułami rządzącymi kategoriami morfologicznymi - należałoby wyróżnić kolejną morfologiczną kategorię określoności/nieokreśloności w języku litewskim.

2.1.4. Język polski nie wykształcił morfologicznej kategorii określoności/nieokreśloności. Dlatego w gramatykach szkolnych problem określoności/ nieokreśloności się nie pojawia. Natomiast w kierowanych do polskiego odbiorcy podręcznikach do nauki języków obcych (tzw. rodzajnikowych) pojawiają się informacje o nieznanej językowi polskiemu kategorii określoności/ nieokreśloności. Nierzadko stwierdza się również, że przedstawiane zjawisko jest obce językowi polskiemu i wymaga szczególnej uwagi, by mogło zostać zrozumiane, por. cytat $\mathrm{z}$ elektronicznego słownika: „Rodzajnik określony odpowiednio dla rodzaju męskiego, żeńskiego i nijakiego, używa się go do określenia konkretnych osób, zwierząt i rzeczy. Nie tłumaczy się na język polski”2.

2.1.4.1. Podobny do polskiego stan obserwujemy w języku rosyjskim. Można w tym miejscu przytoczyć cytaty z podręczników do nauki języków bałtyckich, kierowanych właśnie do odbiorcy rosyjskiego. Pierwszy przykład dotyczy języka łotewskiego: „Употребление прилагательных с неопределенными и определенными окончаниями представляют

\footnotetext{
${ }^{2}$ Hasło der, die, das w Lingea Lexicon 5, ver. 5.0.0.3.
} 
некоторую трудность, поскольку в современном русском языке категория определенности и неопределенности отсутствует"3. Кolejny przykład pochodzi z podręcznika do nauki języka litewskiego: „На русский язык как простые, так и местоименные прилагательные переводятся одинаково"4.

2.1.5. Zamiarem, który towarzyszy prezentacji różnych odmian morfologicznych kategorii określoności/nieokreśloności, jest między innymi ukazanie na ich różnorodność. Przedstawione w punktach 2.1.1.-2.1.3. kategorie zostały zaczerpnięte $\mathrm{z}$ języków indoeuropejskich. Jednak dla pełniejszego obrazu różnorodności możliwych postaci morfologicznych kategorii określoności/ nieokreśloności przedstawia się jeszcze typową dla języka mongolskiego parę opozycyjną: accusatiwu (również, choć rzadziej: locatiwu, locatiwu temporis, genetiwu partitivus, directiwu) do indefinitu. Jest to opozycja przypadków, w której accusativus (i niektóre inne przypadki) uznaje się za człon nacechowany, zaś indefinitus - za człon nienacechowany.

Jak można zauważyć, formalna postać pary opozycyjnej w każdym z przytoczonych przykładów morfologicznych kategorii określoności/nieokreśloności jest swoista. Fakt, można odnaleźć odpowiedniości formalne, np. prepozycję rodzajnika w angielskim i niemieckim czy postpozycję typową dla litewskiego i bułgarskiego, brak rodzajnika nieokreślonego dla liczby mnogiej w niemieckim i angielskim. Jednak nie może być mowy o zestawialności tych kategorii. W każdym języku notujemy inne uwarunkowania kontekstowe dla użycia członu nacechowanego, czyli wyrażenia określonego, oraz członu nienacechowanego, czyli wyrażenia nieokreślonego, jak również inne wypadki neutralizacji formalnego rozróżnienia wyrażeń określonych i nieokreślonych. Właśnie neutralizacja formalnego rozróżnienia wyrażeń określonych i nieokreślonych jest również jedną z cech właściwych kategorii morfologicznej, por. chociażby analogiczne przykłady neutralizacji znaczeń dla języków litewskiego i angielskiego:

1) Mylimasis kalnus nuverstu (przysłowie)

= Mylimas kalnus nuverstu.

dosłownie: 'Ukochany góry by obalił'.

2) The Lithuanian are good people.

= Lithuanian are good people.

2.2.1. Semantyczna kategoria określoności/nieokreśloności w odróżnieniu od wyżej przedstawionych morfologicznych kategorii określoności/

${ }^{3}$ Б.Х. В е ксле р, В.А. Ю р и к, Латышский язык (Latvian language), Puгa 1975, s. 188.

${ }^{4}$ С. Алекса ндр а в и юс, Литовский язык (Lithuanian language), Вильнюс 1988, s. 233. 
nieokreśloności nie jest determinowana płaszczyzną formalną. Można wręcz postawić odwrotną tezę, że to semantyczna kategoria determinuje morfologiczną postać kategorii na tyle, na ile pozwala na to formalna płaszczyzna języka. Tradycyjnie morfologiczna kategoria określoności/nieokreśloności łączona jest $\mathrm{z}$ frazą imienną. Jest to oczywiste, gdy pod uwagę bierze się funkcjonowanie rodzajników, które mogą determinować tylko wyrażenia imienne. W wypadku semantycznej kategorii znaczenia określoności i nieokreśloności ujawniane są nie tylko we frazie nominalnej, lecz również we frazie werbalnej. Skoro kategoria semantyczna nie ogranicza się tylko do frazy imiennej, jest więc kategorią zdaniową. Konsekwencją takiego podejścia jest fakt, że w prezentacji wykładników poszczególnych znaczeń określoności czy nieokreśloności ujawnione zostaną zarówno te należące do frazy imiennej, jak i te należące do frazy werbalnej. Ponadto semantyczna kategoria określoności/ nieokreśloności opisuje poza wykładnikami leksykalnymi i morfologicznymi również wykładniki syntaktyczne, np. charakterystyczne dla zdań podrzędnie złożonych.

Konfrontacja języków w planie kategorii morfologicznych jest metodologicznie błędna. Możliwa jest jednak konfrontacja języków w planie kategorii semantycznych. Wówczas język-pośrednik jako język pojęć określa zakres takiej analizy. Na każdym etapie badań zestawienie języka-pośrednika z każdym językiem z osobna ujawnia wszelkie formalne wykładniki dla danego języka. Wspólne odniesienie sprawia, że uzyskane wyniki badań dla poszczególnych języków są ze sobą zestawialne, porównywalne.

Przyjęcie założeń teoretycznych badań konfrontatywnych (język-pośrednik jako tertium comparationis, kategorie semantyczne) pozwala na adekwatne zestawianie wszelkich języków, niezależnie od tego, czy morfologiczny kategorialny odpowiednik (kategoria morfologiczna) analizowanych znaczeń jest obecny w jednym, w wielu, we wszystkich czy też w żadnym $\mathrm{z}$ analizowanych języku. Zgodnie $\mathrm{z}$ założeniami teoretycznych badań konfrontatywnych najpierw definiuje się znaczenie, czyli język-pośrednik konkretnej kategorii semantycznej, następnie do tego języka-pośrednika przyrównuje się każdy poddawany analizie język. W ten sposób dla każdego języka wyodrębnione zostają wszelkie wykładniki formalne, które są w stanie wyrazić znaczenia zdefiniowane w języku-pośredniku. Stopień rozczłonkowania znaczeń w języku-pośredniku determinuje liczbę grup wykładników, z których każda przyporządkowana jest konkretnemu znaczeniu (podkategorii). 


\section{Rozwój języka-pośrednika}

Język-pośrednik podlega ciągłemu rozwojowi. Z jednej strony można mówić o rozwoju związanym z kontynuacją badań konfrontatywnych nad nowymi znaczeniami dla konkretnego zestawu języków. $Z$ drugiej zaś strony o rozwoju języka-pośrednika rozumianym jako uaktualnienie/przysposobienie do badań konfrontatywnych nowych języków. Poniżej zostanie przedstawiony przykład rozwinięcia języka-pośrednika poczynionego celem konfrontacji tych samych znaczeń dla nowych języków.

W drugim tomie Gramatyki konfrontatywnej bułgarsko-polskiej (Koseska, Gargov 1990) zostaje zdefiniowany język-pośrednik semantycznej kategorii określoności/nieokreśloności. Podstawą fundującą język-pośrednik tej kategorii jest teoria kwantyfikacyjna. W oparciu o opozycyjne znaczenia jednostkowości i niejednostkowości zostaje wyróżniona podstawowa opozycja określoności do nieokreśloności. Jednostkowość obejmuje znaczenia jednostkowości elementu lub zbioru spełniającego predykat. Niejednostkowość to znaczenia egzystencjalności i ogólności. Treści określoności i nieokreśloności zostają ujawnione nie tylko we frazie nominalnej (jak to ma miejsce w opisie morfologicznej kategorii określoności/nieokreśloności), lecz również we frazie werbalnej. Tym samym semantyczna kategoria określoności/nieokreśloności rozumiana jest jako kategoria zdaniowa. Koseska i Gargov (1990) różnicują siłę znaczenia kwantyfikacyjnego w oparciu o porządek kwantyfikatorów w semantycznej strukturze zdania. Najszerszy zasięg kwantyfikatora upoważnia autorów do przypisania mu silnych znaczeń kwantyfikacyjnych. Natomiast kwantyfikator, pozostający w zasięgu innych kwantyfikatorów, charakteryzują słabe znaczenia kwantyfikacyjne. Poniżej zostają przedstawione bułgarskie, polskie i litewskie przykłady ilustrujące podstawowe - zgodnie z wyżej przedstawionymi założeniami - znaczenia kwantyfikacyjne ${ }^{5}$ :

- Znaczenie jednostkowości elementu

3) Въпрос: Бертон, не намираш ли, че отговорът ти е нелогичен?

Pytanie: Nie uważasz, Berton, że twoja odpowiedź jest nielogiczna?

Klausimas: Ar nemanai, Bertonai, kad tavo atsakymas nelogiškas?

$\mathrm{W}$ przedstawionych zdaniach zauważalna jest odpowiedniość bułgarskiego wyrażenia złożonego z rodzajnikiem oтговорът $m u$ do polskiego twoja odpowiedź i litewskiego tavo atsakymas. Zarówno polski, jak i litewski odpo-

${ }^{5}$ Przytaczane tu przykłady z języków bułgarskiego, polskiego i litewskiego pochodzą z zasobów eksperymentalnego równoległego bułgarsko-polsko-litewskiego korpusu. 
wiednik są wyrażeniami złożonymi, zawierającymi formy przymiotników ${ }^{6}$ (zaimków) pol. twój i litew. tavo.

- Znaczenie jednostkowości zbioru

4) - Хората имат пушки - каза лисицата - и ходят на лов. Много е неприятно! Отглеждат и кокошки. Интересува ги само това. Ти кокошки ти тьрсиш?

- Ludzie maja strzelby i poluja - powiedział lis. - To bardzo kłopotliwe. Hoduja także kury, i to jest interesujace. Poszukujesz kur?

- Žmoness, tarè lapé, - turi šautuvus ir medžioja. Tai gerokai varžo! Be to, jie laiko vištas. Jomis jie ir tesirūpina. Tu ieškai vištų?

W przykładzie 4 bułgarskiemu wyrażeniu z rodzajnikiem xopama odpowiadają pol. ludzie i litew. žmonès. Są to wyrażenia, które charakteryzuje niedopowiedzenie językowe. Jedynie kontekst i sytuacja decydują o znaczeniu kwantyfikacyjnym tych wyrażeń. Warto zwrócić uwagę, że w języku litewskim w następującym kontekście dwukrotnie pojawia się forma jie 'oni', w języku bułgarskim zaś - jednokrotnie $2 u$, które również są wykładnikami jednostkowości zbioru. W języku polskim, czyli w języku o najniższym stopniu formalizacji znaczeń określoności/nieokreśloności, obserwujemy niedopowiedzenie językowe, tzw. zero leksykalne.

- Znaczenie egzystencjalności

5) В ияллата тази плетеница от думи имаше нещзо, което аз не можех да схвана.

Był w tym jakiś element, którego nie umiałem pochwycić.

Čia buvo kažkas, ko aš niekaip negalèjau užčiuopti.

Znaczenia egzystencjalności w trzech zestawianych językach zostają wyrażone za pomocą rzeczowników (zaimków) w bułgarskim (нещьo) i litewskim (kažkas) oraz wyrażenia złożonego w polskim (jakiś element). W oparciu o (Roszko 2004) można dodać, że jedynie litewska forma kažkas jest jednoznacznym wykładnikiem znaczeń egzystencjalnych. Zarówno bułg. нещо, jak i pol. jakiś element są wieloznacznymi wykładnikami, które mogą - w zależności od kontekstu i sytuacji - wyrażać kwantyfikację egzystencjalną lub ogólną.

- Znaczenie ogólności

6) Всички кокошки си приличат и всички хора си приличат.

Wszystkie kury sa do siebie podobne i wszyscy ludzie sa do siebie podobni.

${ }^{6} \mathrm{~W}$ artykule zastosowano klasyfikację części mowy zgodną z (S a lon i, Grus z czyń ski, Woliński, Wołosz 2007). 
Visos vištos tarp savęs panašios, ir visi žmonès tarp savęs panašūus. W przykładzie 6 stwierdza się identyczny sposób wyrażenia znaczeń ogólnych $\mathrm{w}$ trzech zestawianych językach. Są to bowiem wyrażenia złożone, w których formy przymiotnikowe bułg. всички, pol. wszystkie/wszyscy i litew. visos/visi jednoznacznie determinują rodzaj kwantyfikacji ogólnej.

Wyjaśnienia wymaga różnica między znaczeniami jednostkowości zbioru i ogólności, bowiem jest ona subtelna.

W wypadku jednostkowości zbioru mówimy o tym jedynym w swoim rodzaju zbiorze, który spełnia predykat. Aby uwydatnić znaczenia kwantyfikacyjne jednostkowości zbioru zawarte w przykładzie 4 można podane w nim zdania uzupełnić o leksemy bułg. самo, pol. tylko/jedynie litew. tik/tiktai, np.:

4а) - Само хората имат пушки - каза лисицата - и ходят на тов.

Много е неприятно! Отглеждат и кокошки. Интересува ги само това. Ти кокошки ли тьрсиш?

- Tylko ludzie maja strzelby i poluja - powiedział lis. - To bardzo kłopotliwe. Hoduja takize kury, i to jest interesujące. Poszukujesz kur?

- Tiktai žmoness, taré lapé, - turi šautuvus ir medžioja. Tai gerokai varžo! Be to, tiktai jie laiko vištas. Jomis tiktai jie ir tesirūpina. Tu ieškai vištų?

W wypadku ogólności zbiór będący przedmiotem dyskursu nie jest tym jedynym zbiorem, lecz jednym $\mathrm{z}$ wielu możliwych, bowiem nie tylko o ludziach możemy twierdzić, że są wzajemnie do siebie podobni.

Jak można zauważyć, w opisie znaczeń semantycznej kategorii określoności/nieokreśloności jest uwzględniany nie tylko kontekst, lecz i (kon)sytuacja. Uwzględniane w interpretacji minimum wspólnej dla nadawcy i odbiorcy wiedzy o świecie pozajęzykowym jest elementem sytuacyjnym. Podane w przykładzie 6 zdania można zubożyć o leksemy pol. wszystkie/wszyscy, litew. visos/ visi, zachowując przy tym stałość znaczeń kwantyfikacyjny ogólnych, por::

6a) Kury sa do siebie podobne i ludzie sa do siebie podobni.

Vištos tarp savęs panašios, ir žmonès tarp savęs panašūs.

Kompetencja językowa potwierdzona analizą korpusową ujawniła, że stworzony z myślą o bułgarsko-polskiej konfrontacji język-pośrednik (Koseska, Gargov 1990) nie odkrywa pewnych charakterystycznych dla języka litewskiego regularności. Dlatego też wyjątkowo dla celów litewsko-polskiej konfrontacji rozbudowano wspomniany język-pośrednik. Wprowadzono zatem gradację znaczeń egzystencjalności, wyróżniając nowe podkategorie: egzystencjalności presuponującej jednostkowość i egzystencjalności właściwej. 
Na podobnej teoretycznej podstawie (gradacji znaczeń) wyróżniono podkategorie ogólności - ogólności zwyczajowej i ogólności właściwej. Ponadto wprowadzono pojęcia jednoznacznego i niejednoznacznego wykładnika znaczenia kwantyfikacyjnego. Również i w tym wypadku za rozróżnieniem jednoznacznych/niejednoznacznych wykładników poszczególnych znaczeń określoności i nieokreśloności przemawiały fakty z języka litewskiego, w którym to właśnie języku zaobserwowano wysoką konsekwencję w rozróżnianiu znaczeń kwantyfikacyjnym już na płaszczyźnie formalnej.

Poniższe przykłady są ilustracją nowo wyróżnionych podkategorii:

- Znaczenie egzystencjalności presuponującej jednostkowość

7) Przez pewien czas popularny był (rozpowszechniany gorliwie przez prase codzienna) pogląd, że myślacy ocean, który opływa cała Solaris, jest gigantycznym mózgiem, przewyższającym nasza cywilizacje o miliony lat rozwoju, że to jakiś „kosmiczny yoga”, mędrzec, upostaciowana wszechwiedza, która dawno już pojęła płonność wszelkiego działania i dlatego zachowuje wobec nas kategoryczne milczenie.

Tam tikra laika buvo populiari (uoliai laikraščiu skleidžiama) pažiūra, kad mąstantis okeanas, kuris supa visa Soliari, yra gigantiškos smegenys, kurios, besivystydamos milijonus metu, pranoko mūsu civilizaciją. Tai esąs kažkoks „kosminis jogas”, išminčius, įkūnyta visažinybè, kuri jau seniai suvoke bet kokios veiklos bevaisiškuma ir todèl kategoriškai atsisako su mumis bendrauti.

W ukazanych wyżej zdaniach polskiemu wyrażeniu złożonemu przez pewien czas odpowiada litewskie wyrażenie złożone tam tikra laika. W obu wyrażeniach złożonych zostały użyte przymiotniki (pol. pewien i litew. tam tikras), które między innymi w pracach S. Karolaka są definiowane jako eluzywne (Karolak 2001), por. też (Veyrenc 1985).

- Znaczenie egzystencjalności właściwej

8) Gdzieś, wysoko, posłyszałem przeciąłe zgrzytanie i równocześnie otoczenie pojaśniało.

Kažkur aukštai išgirdau pratisa džeržgesį, ir viskas aplinkui nušvito.

W wypadku tych zdań wyrażanie znaczeń egzystencjalności właściwej przypisuje się wyrażeniom prostym pol. gdzieś, litew. kažkur. Są to przysłówki, których użycie Karolak definiuje jako tetyczne (Karolak 2001).

${ }^{7}$ Przytaczane tu przykłady z języków polskiego i litewskiego pochodzą z zasobów eksperymentalnego równoległego polsko-litewskiego korpusu. 
- Znaczenie ogólności zwyczajowej

9) Normalnie, kto żyw biegnie na lotnisko, kiedy przybywa ktoś nowy, i do tego jeszcze prosto $z$ Ziemi.

Normaliai visi kas gyvas bèga į nutūpimo aikštelę, kai atvyksta kas naujas, be to, dar tiesiai iš Žemès.

10) - No i co, dowiedziateś się czegoś? - spytał.

- Na kaip, sužinojai ka nors? - paklausé.

W zdaniach 9-10 obserwujemy dwie pary ekwiwalentnych wyrażeń: pol. ktoś nowy - litew. kas naujas i pol. czegoś - litew. ka nors. W wypadku języka polskiego $\mathrm{w}$ obu cytowanych zdaniach pojawia się forma $\mathrm{z}$ formantem $-s$. W zależności od przyjętej podstawy wyróżnienia części mowy pol. ktoś i coś można uznać za zaimki (tradycyjne podejście) lub za rzeczowniki (Saloni, Gruszczyński, Woliński, Wołosz 2007). D. Roszko i R. Roszko w opracowanej propozycji wspólnego dla języków polskiego i litewskiego tagsetu cech morfosyntaktycznych zarówno wymienione wyżej polskie formy ktoś i coś, jak i litewskie kas i kas nors interpretują jako rzeczowniki (Roszko, Roszko 2009). Warto zwrócić uwagę, że w zasadzie dla języka polskiego w zdaniach 9-10 wyrażenia bazują na formach $\mathrm{z}$ formantem -ś. W języku litewskim odpowiadają im dwie różne formy kas (naujas) i kas nors (z postpozycyjną nieodmienną cząstką nors). Litewskie formy (kas i kas nors) są funkcjonalnie tożsame. Należy odnotować, że w pracach S. Karolaka przedstawione w zdaniach 9-10 użycie form $\mathrm{z}$ formantem -ś jest definiowane jako hipotetyczne (Karolak 2001).

- Znaczenie ogólności właściwej

11) Pierwsze cztery dni po tej zmianie metodyki upłynęty bez jakichkolwiek wypadków, jeśli nie liczyć trafiających się od czasu do czasu uszkodzeń aparatury tlenowej skafandrów, gdyż wylotowe zawory okazały się wrażliwe na korodujace działanie trujacej atmosfery.

Pirmosios keturios dienos po šitu pakeitimu praejo be jokiu ịvykiu, tik kartas nuo karto sugesdavo skafandrų deguonies aparatūra, kadangi išmetimo vožtuvai pasirodè esa jautrūs nuodingos atmosferos veikimui.

W przykładzie 11 polskie wyrażenie złożone jakichkolwiek wypadków koresponduje $\mathrm{z}$ litewskim jokiu įvykiu. W obu tych wyrażeniach pojawiają się przymiotniki pol. jakikolwiek i litew. joks. Te właśnie formy sprawiają, że kwantyfikacja wyróżnionych wyrażeń jest interpretowana jako ogólna właściwa. W pracach S. Karolaka tego typu użycia wspomnianych form są definiowane jako antytetyczne (Karolak 2001). 
Język-pośrednik zmodyfikowany w wyżej wyszczególniony sposób nie narusza założeń teorii, które legły u podstaw powstałego na potrzeby konfrontacji języków bułgarskiego i polskiego. Jest jedynie jego rozwinięciem. Nowo powstały język-pośrednik może być podstawą do innych badań. W języku-pośredniku zastosowanym w przygotowywanej Polsko-litewskiej gramatyce konfrontatywnej wprowadza się rozróżnienie wykładników jednoznacznych i wieloznacznych. Za wykładnik jednoznaczny uznany zostaje ten, który w każdym możliwym kontekście wyraża dokładnie jedno i to samo znaczenie. Kwalifikator jednoznaczny wykładnik znacznie usprawnia komputerowe przetwarzanie języka.

\section{Podsumowanie}

Zespół Semantyki Instytutu Slawistyki PAN, opracowując podstawy teoretycznych badań konfrontatywnych, dowiódł, że możliwe jest zestawienie dwu lub więcej języków, które spełnia wymogi naukowości. Wprowadzony jako podstawa teoretycznych badań konfrontatywnych język-pośrednik stanowi tertium comparationis tej konfrontacji językowej. Język-pośrednik jest sztucznym językiem spójnych i prostych reguł, który na każdym etapie badań jest rozbudowany, oraz stanowi odniesienie dla każdego z zestawianych języków. Język-pośrednik stawiany jest na tym samym poziomie, co zestawiane języki. Języka-pośrednika nie można utożsamiać z metajęzykiem, czyli językiem opisu.

\section{Literatura}

Dimitrova L., Koseska-Toszewa V., Roszko D., Roszko R., 2010, Application of Multilingual Corpus in Contrastive Studies (on the example of the Bulgarian-Polish-Lithuanian Parallel Corpus), „Cognitive Studies. Etudes Cognitives” 10, s. 217-239.

Ka rolak S., 2001, Od semantyki do gramatyki, Warszawa.

Koseska V., Gargov G., 1990, Българско-полска съпоставителна граматика. Том 2. Семантичната категория определеност/неопределеност, София.

Koseska V., Korytkowska M., Roszko R., 2007, Polsko-bułgarska gramatyka konfrontatywna, Warszawa.

Koseska V., Korytkowska M., Roszko R., 2009, Contrastive Studies and Semantic Interlanguage, „Cognitive Studies. Etudes Cognitives” 9, s. 33-52.

Ko se ska V., Mazurki ewicz A., 2010, Time flow and tenses, Warszawa.

Koseska V., Penčev J. (red.), 1988-2009, Gramatyka konfrontatywna bułgarsko-polska, t. I-IX, Sofia - Warszawa. 
Projekt 1984: Projekt gramatyki konfrontatywnej bułgarsko-polskiej i serbskochorwacko-polskiej,

[w:] Studia polsko-południowosłowianskie, red. K. Pola ń ski, Wrocław.

R o s zko D., 2006, Funkcjonalne odpowiedniki litewskiego perfectum w litewskiej gwarze puńskiej $i$ w jezzyku polskim, Warszawa.

Roszko D., Roszko R., 2009, Morphosyntactic Specifications for Polish and Lithuanian.

[Description of Morphosyntactic Markers for Polish and Lithuanian Nouns within MUL-

TEXT-East Morphosyntactic Specifications (Version 3.0 May 10th, 2004)], [w:] Representing Semantics in Digital Lexicography Innovative Solutions for Lexical Entry Content in Slavic Lexicography, MONDILEX Fourth Open Workshop Warsaw, Poland, 29 June

- 1 July, 2009, red. V. Kos eska - Tos zewa, L. Dimitrova, R. Ros zko, Warszawa. Roszko D., Roszko R., w przygotowaniu, Polsko-litewska gramatyka konfrontatywna.

Ros zko R., 1993, Wykładniki modalności imperceptywnej w języku polskim i litewskim, Warszawa.

Roszko R., 2004, Semantyczna kategoria określoności/nieokreśloności w języku litewskim ( $w$ zestawieniu $z$ językiem polskim), Warszawa.

Saloni Z., Gruszczyński W., Woliński M., Wołosz R., 2007, Słownik gramatyczny języka polskiego (wersja 1.0), edycja komputerowa.

S elinker L., 1972, Interlanguage, „Iral” 10-3, s. 209-213.

Veyrenc J., 1985, Les pronoms indéfinis en français et en russe, [w:] Atti del colloquio lingue slave et lingue romanze: un confronto, Firenze, s. 1-19.

\section{Theoretical contrastive studies}

\section{(Summary)}

The contrastive studies criticism in the $60 \mathrm{~s}-70 \mathrm{~s}$ of the $20^{\text {th }}$ century was the only basis for quite a few researchers to formulate their opinion on the studies. Although the criticism is becoming out-of date, it has not lost its inertia to disapprovingly dispose to and discourage from contrastive studies. It should be emphasized that the contrastive studies have taken quite a different course since then. The key charge of the lack of a solid basis for the combination of the languages is no longer in effect. The contrastive studies guidelines formed from scratch by the Semantics Research Team of the Institute of Slavic Studies of the Polish Academy of Science are evidence for it, successfully finding their application in previously published multi-volume monographs (Koseska, Penčev 1988-2009), (Korytkowska, Koseska, Roszko 2007), a number of works of the authorship of S. Karolak, M. Korytkowska, V. Koseska, V. Maldjieva, D. Roszko, R. Roszko and others (compare the bibliography in Korytkowska, Koseska, Roszko 2007), as well as in the Polish- 
Lithuanian Contrastive Grammar in preparation by D. Roszko, R. Roszko. The fundamental principle of the contrastive studies is orienting the studies from the semantic ground (the interlanguage) to the formal ground. Using the interlanguage as a semantic tertium comparationis creates a solid and explicit basis for the combination of the languages. The bases for theoretical contrastive studies have come into existence at the Institute of Slavic Studies. Therefore, the guidelines for them were applied for the contrast of Slavonic languages (mainly Polish and Bulgarian). Afterwards, the Lithuanian language, belonging to the Baltic Languages, was included among the languages being contrasted. It is noticeable that the studies itself and the published works based on the criteria of theoretical contrastive studies refer to less popular and poorly spread languages, that is Polish, Bulgarian and Lithuanian. Moreover, for quite a time the majority of these works were published mainly in Polish and Bulgarian. Despite a few decades of the existence of the new linguistic contrastive method, the above-mentioned facts caused that the method isn't well-known. The idea of this article is to make the researchers get interested in the guidelines for theoretical contrastive studies and the results of some of the linguistic contrasts carried out until now. 